\title{
The Processing of Pictures and Written Words: A Perceptual and Conceptual Perspective
}

\author{
Paul Miller \\ Department of Education University of Haifa, Haifa, Israel. \\ Email: mpaul@construct.haifa.ac.il \\ Received May 22 ${ }^{\text {nd }}$, 2011; revised July 19 th $^{\text {th }}$ 2011; accepted August 22 ${ }^{\text {nd }}, 2011$.
}

\begin{abstract}
The present study examines similarities and differences in the processing of drawings and their corresponding names. For this purpose, students were asked to determine as fast as possible the identicalness of two pictures as opposed to the identicalness of their written Hebrew names. Twenty-eight Hebrew native speakers from the fifth grade participated in the experiment. Findings suggest that the human information processing system optimizes the processing of information (words, drawings, etc.) according to specific task requirements or task constraints. Stimulus type per se does not seem to determine the depth of its processing, nor does it seem to directly trigger particular modalities of encoding (perceptual, linguistic, semantic). Finally, the findings warrant the conclusion that superiority effects related to the processing of written words and pictorial stimuli reflect artifacts of task requirements rather than inherent characteristics of stimuli.
\end{abstract}

Keywords: Coding, Words, Pictures

\section{Introduction}

Questions regarding the processing of written words as opposed to pictorial stimuli have been the impetus of a vivid line of research for more than a century. Findings from such endeavors have revealed substantial differences in the processing of these two stimulus types and have become the basis for an improved understanding of the human information processing system, an understanding that has been conceptualized in increasingly sophisticated theoretical models. One of these models is the Dual Coding Theory of Paivio (1986, 1991), which assumes that, to process pictures and written words, individuals code them in two essentially different ways-one attuned to their imagery features and the other to their verbal properties. The present study examines similarities and differences in the processing of schematic drawings and their corresponding names to further validate the hypothesized characteristics of such a dual coding theory, as well as to elucidate its constraints.

A frequent approach to clarifying differences in the processing of pictures and written words has focused on memory performance. Findings overwhelmingly suggest that retention is notably better for pictures than for words (McBride \& Dosher, 2002; Paivio \& Csapo, 1973; Weldon \& Coyote, 1996; Weldon \& Roediger, 1987; Wippich, Melzer, \& Mecklenbrauker, 1998). According to Paivio (1986, 1991, 1995), such increased memory performance reflects the fact that, upon their encounter, pictures elicit both a verbal code and an image code, whereas for written words, processing confines itself to verbal coding. However, this conclusion seems problematic when taken in a strict sense, given that turning individuals' attention to semantic aspects of the to-be recalled pictures and words (rating their pleasantness) during encoding was found to eliminate the picture superiority effects (Paivio, 1975). Such evidence seems to suggest that picture superiority effects observed in recall experiments are triggered by task requirements at the stage of stimulus encoding that determine depth of processing.

Another explanation proposed in the literature argues that picture superiority effects reflect variance in the degree of per- ceptual distinctiveness of pictures and words. According to this line of thinking, because pictures are more distinct from each other, they become encoded in more detail, which facilitates their future recall (Nelson, 1979). Indeed, experimentally manipulating the perceptual distinctiveness of pictures was found to have a significant impact upon the occurrence of picture superiority effects (Nelson, Reed, \& Walling, 1976). In other words, keeping the similarity between pictures low significantly increased their recall relative to words, whereas increasing similarity between pictures resulted in the disappearance of the picture superiority effects.

A more recent approach to explaining picture superiority effects in recall has been proposed in the form of a transfer-appropriate processing theory (TAP) (McBride \& Dosher, 2002; Weldon \& Roediger, 1987). According to this approach, picture superiority effects are rooted in peculiarities related to the initial encoding of the stimulus in conjunction with peculiarities related to the future retrieval of the same stimulus. In other words, the processing of particular properties of a stimulus at study (during encoding) should benefit its future retrieval only if these encoded properties are relevant for task performance (McBride \& Dosher, 2002). Given this to be true, it should not be surprising that pictures-which at the moment of encounter are assumed to trigger their meanings-show increased recall/recognition rates in comparison to words, for which processing is likely to stop before their semantics become fully activated (Potter, Kroll, Yachzel, Carpenter, \& Shermann, 1986).

The above explanations of the picture superiority effects in recall all postulate essential differences between pictures and words during encoding. Hence, their credibility depends on whether such differences can be demonstrated, and what their nature is. During the last three decades, questions regarding the way pictures as opposed to words become encoded at encounter have stimulated extensive research employing varied experimental paradigms. Such endeavors have pinpointed notable differences between the processing of these two stimulus types. For example, it has been shown that words are named faster 
than pictures (Lloyd-Jones \& Humphreys, 1997), but when individuals are asked to categorize these two stimulus types, the opposite was the case (Job, Rumiati, \& Lotto, 1992).

A possible explanation for this inconsistent processing pattern is that, to name a picture, its phonology (name) has to be retrieved via its meaning, whereas to name a word, its lexical or even sublexical processing may be sufficient (McCann \& Besner, 1987), without the need to activate its semantics. On the other hand, in order to categorize both pictures and words, the activation of their semantic representations (meaning) is necessary. Pictures seem to trigger their meaning in a straightforward manner. In contrast, the retrieval of the semantics of wordsnecessary for their categorization-is hypothesized to be less direct, mediated by linguistic (phonological/orthographic) knowledge that, in a initial step, must be retrieved from permanent memory (Jackson \& Coltheart, 2001). If these assumptions are true, the asymmetric processing pattern found for these two stimulus types makes sense.

However, findings from a more recent experiment designed to track differences in the processing of pictures and words challenges the assumption that the naming of pictures involves two consecutive processing phases (Job \& Tenconi, 2002). In this experiment, the researcher used a paradigm with an ordinary naming condition and a combined categorization/naming condition. In the latter condition, participants were instructed to name the stimulus only when it belonged to a predetermined category. As expected, naming-onset latencies were significantly shorter for the ordinary condition than for the combined categorization/naming condition. This is in line with the assumption that ordinary word naming does not involve retrieval of word meaning. Interestingly, however, the naming of pictures in the combined categorization/naming condition was not found to produce longer naming-onset latencies than naming pictures in the ordinary condition. Such a zero cost was rather unexpected. It suggests that the name of a picture is retrieved as a part of accessing its meaning, rather than subsequent to it.

The findings from the Job and Tenconi study (2002) suggest that drawing referential connections from written words to meaning may not be integrated into the process underlying the naming of words. It appears that the activation of inferential connections in this direction has a tandem rather than a simultaneous nature. On the other hand, establishing referential connections from meaning to linguistic entries seems to be an inherent component of the process by which individuals access the meaning of pictures. In Paivio's (1986) terms, pictures, at their encounter, naturally elicit a dual code (their meaning and name), while the encoding of words may be restricted to the retrieval of their linguistic properties (phonological/orthographic knowledge), without spontaneously accessing their meaning.

The present study was conducted to extend knowledge regarding differences in the encoding and processing of words as opposed to pictorial stimuli (drawings). The focus of the study was on the further clarification of two specific questions. Firstly, is the linguistic encoding (e.g., naming) of words, but in particular that of pictorial stimuli, an automatic reaction to their initial encounter? It may be, for example, that the processing of pictures leads to dual coding only in instances where individuals process such stimuli with the intention of naming them (as was the case in Job \& Tenconi, 2002). To economize their processing resources, individuals may skip the retrieval of this information in instances where naming is not an explicit task requirement. Secondly, do differences in the processing of words and pictures depend upon the depth of the required proc- essing?

To answer these questions, a research paradigm derived from the Posner procedure (see Posner \& Mitchell, 1967) was developed. The paradigm asked participants to make rapid identicalness judgments (same/different) for the items comprising a series of stimulus pairs. The items used to building the stimulus pairs were either drawings or the written names of these drawings.

The paradigm manipulated two basic processing dimensions. The first dimension was aimed at determining the minimal level (depth) of processing required to make an identicalness decision for the stimuli. The manipulation of this dimension resulted in two distinct experimental conditions. In the first of these conditions (PI), the identicalness of the two items in a stimulus pair was physical (displayed exactly the same word or drawing twice). To make an identicalness decision in this condition, processing the perceptual properties of the stimuli should be sufficient (see also Posner \& Mitchell, 1967). In the second condition (NI), the identicalness of the two items in a stimulus pair was merely a name identity - two words or drawings that, though physically distinct, evoke the same name (e.g., DOG/dog; drawings of two physically dissimilar dogs). To make an identicalness decision in this condition, the items of a stimulus pair must be processed beyond the perceptual level. Indeed, previous research has shown that making identicalness judgments for real words presented under the NI condition is notably faster than for homophonic pseudo-words (Miller, 2005). This suggests that, to make such identicalness judgments, individuals process letter strings down to their lexical representations.

The second processing dimension manipulated by the paradigm was the syllabic length of the names of the processed stimuli. The manipulation of this dimension also created two distinct experimental conditions. In the first condition, the names of the items in stimulus pairs were monosyllabic; in the second condition, they were bisyllabic. Given that determining the identicalness of two name-only identical items is mediated by their phonological representations, the syllabic length of the item names should impact the speed of their processing.

The final design of the study was 2 (stimulus type-drawings vs. written words) $\times 2$ (identicalness type-physical vs. name) $\times 2$ (syllabic length-monosyllabic vs. bisyllabic).

\section{Research Hypotheses}

Hypothesis 1: participants will process the identicalness of stimulus pairs (words and drawings) in the NI condition notably slower than the identicalness of stimulus pairs in the PI condition. As argued earlier, in the NI condition, determining the identicalness of two items requires retrieval of knowledge from long-term memory (LTM) to bridge the visual incongruity between the two words at the perceptual level—a time-consuming process, whereas in the PI condition, such a decision is possible based solely upon the perceptual properties of the items comprising the stimulus pairs.

Hypothesis 2: participants will elicit a different processing profile in determining the identicalness of words as opposed to the identicalness of drawings, but only in the NI condition, where determining between-stimuli identicalness requires processing the items beyond a perceptional level. Specifically, processing the identicalness of two words in the NI condition (e.g., DOG/dog) will be significantly faster than processing the identicalness of two drawings. This is because determining the identicalness of written words becomes possible by the mere comparison of their verbal properties, without referencing their meaning (McCann \& Besner, 1987; see also Jackson \& 
Coltheart, 2001). In contrast, determining the identicalness of two perceptually different drawings of a particular item (e.g., drawings of two physically dissimilar dogs) requires their processing down to the semantic level (Job, Rumiati, \& Lotto, 1992; Job \& Tenconi, 2002).

Hypothesis 3: determining the identicalness of two written words in the NI condition will be biased by variance in their syllabic length. Specifically, in the NI condition, determining the identicalness of two monosyllabic words will be faster than determining the identicalness of two bisyllabic words. A similar speed of processing difference was predicted between drawings with monosyllabic and bisyllabic names, given that, in the course of processing their identicalness, their linguistic properties become automatically revealed (Job \& Tenconi, 2002). If, however, retrieving their names is restricted to instances where it is explicitly required (i.e., asking participants to determine whether two drawings rhyme), processing the identicalness of drawings in the present study should prove insensitive to syllabic length.

\section{Method}

\section{Participants}

Twenty-eight students randomly sampled from two 5th grade classes in a public school in northern Israel participated in the experiment. For all, Hebrew was their mother tongue. They all had proper hearing and intact or corrected-to-normal vision, and none were diagnosed as having a learning disability. According to their teachers, they all had average or higher reading comprehension skills.

\section{Design and Stimuli}

The study comprised eight experimental conditions, each comprised of 40 stimulus pairs. In each condition, the task was to determine whether the two items comprising a particular stimulus pair are the same or different. The stimulus pairs of each condition were randomly distributed within 40 rectangular fields, arranged in five rows on an A3 sheet (see Appendix A). In half of the fields, the items in a pair were the same; in the other half, the items were different. Participants were asked to mark, as fast as possible, a $\checkmark$ in fields with two identical items and an $\mathbf{X}$ for pairs of two distinct items. For each experimental condition, a practice sheet with some additional stimulus pairs served for task explanation and practice.

Figure 1 illustrates all eight conditions. In four of the eight experimental conditions (hereafter "word conditions"), stimulus pairs were built from written Hebrew nouns representing familiar items. The other four conditions (hereafter "drawing conditions”) were an exact replication of the four word conditions, except that drawings were used to build the stimulus pairs. The following description of the principles underlying the creation of the different experimental conditions is provided only for the four word conditions. The very same principles, however, are applicable also to the drawing conditions of the experiment.

In two of the word conditions, the two items comprising an identical stimulus pair were physically identical (PI). In the other two word conditions, the two items in an identical stimulus pair were merely name identical (NI). In one of the PI word conditions and one of the NI word conditions, all the items used to build the stimulus pairs had monosyllabic names; in the remaining two word conditions, they all had bisyllabic names. As a result, processing the items in the monosyllabic word conditions verbally (phonologically) required the processing of 80 syllables per experimental sheet, whereas the number of syllables to be processed in the bisyllabic word conditions was twice this amount.

Twenty Hebrew words (nouns) were used to prepare the stimulus pairs of the four word conditions of the experiment. All were concrete high-frequency words (see Appendix B, Stimuli Transcription). They were all written as trigrams in

\begin{tabular}{|c|c|c|c|c|c|c|c|c|}
\hline & \multicolumn{4}{|c|}{ Physically Identical (PI) } & \multicolumn{4}{|c|}{ Name Identical (NI) } \\
\hline \multirow[t]{2}{*}{$\begin{array}{l}\text { Syllabic } \\
\text { Length }\end{array}$} & \multicolumn{2}{|c|}{$\checkmark$ Response } & \multicolumn{2}{|c|}{ X Response } & \multicolumn{2}{|c|}{$\checkmark$ Response } & \multicolumn{2}{|c|}{ X Response } \\
\hline & \multicolumn{8}{|c|}{ Word Pairs } \\
\hline Monosyllabic & $\begin{array}{l}\text { תוף } \\
\text { (drum) }\end{array}$ & $\begin{array}{l}\text { תוף } \\
\text { (drum) }\end{array}$ & $\begin{array}{c}\text { פיל } \\
\text { (elephant) }\end{array}$ & $\begin{array}{l}\text { תוף } \\
\text { (drum) }\end{array}$ & $\begin{array}{l}\text { תוף } \\
\text { (drum) }\end{array}$ & $\begin{array}{l}\text { プ/カ } \\
\text { (DRUM) }\end{array}$ & $\begin{array}{c}\text { פיל } \\
\text { (Elephant }\end{array}$ & $\begin{array}{l}\text { f/ת } \\
\text { (DRUM) }\end{array}$ \\
\hline Bisyllabic & $\begin{array}{r}\text { ברז } \\
\text { (faucet) }\end{array}$ & ברז & $\begin{array}{c}\text { טוס } \\
\text { (peacock) }\end{array}$ & ברז & | & $\begin{array}{c}\text { รว } \\
\text { (FAUCET) }\end{array}$ & $\begin{array}{c}\text { טוס } \\
\text { (peacock) }\end{array}$ & $\begin{array}{l}\text { Зว } \\
\text { (FAUCET) }\end{array}$ \\
\hline \multicolumn{9}{|c|}{ Drawing Paris $^{a}$} \\
\hline Monosyllabic & ind & in & & Evos & ind & & & \\
\hline Bisyllabic & స్తా & స్తా & 28 & స్యా & న్య & . & (1) & .26 \\
\hline
\end{tabular}

Figure 1.

Illustration of the eight experimental conditions. ${ }^{a}$ The drawing pairs are presented in a size that is somewhat reduced relative to their appearance on the test sheets. 
unpointed Hebrew. ${ }^{1}$ Half were monosyllabic words and the remainder bisyllabic words. They all represented objects that could be converted into simple schematic drawings so as to create the four drawing conditions of the experiment.

Preparation of the word pairs involved several steps. First, ten identical and ten non-identical word pairs were created from the ten items of the monosyllabic word pool. Second, the 20 monosyllabic word pairs were duplicated, making a total of 40 monosyllabic word pairs-half of them comprised of the same word twice and the other half of two different words. The same procedure was also applied to the items of the bisyllabic word pool. Third, in each condition (PI and NI), both for monosyllabic and bisyllabic words, half of the pairs built from two identical words and half of the pairs built from two different words were presented in print; the other half were presented in a cursive typescript (see Figure 1 and Appendix B). The reason for using two typescripts in the PI condition, as in the NI condition, was to equate typescript-related word processing differences (see, e.g., Corcoran \& Rouse, 1970; De Zuniga, Humphreys, \& Evett, 1991). Finally, each of the four word pair sets (identical print; non-identical print; identical cursive; non-identical cursive) was randomly distributed within the 40 fields of a test sheet, each test sheet representing a specific word condition (e.g., Appendix A-test sheet of PI condition for monosyllabic words).

The four drawing conditions of the experiment were prepared as an exact copy of the four word conditions, with each word being replaced by a simple schematic drawing denoting the same concept as the word. To allow for the creation of the NI drawing conditions, two drawings were produced for each noun. These drawings - though they represented the same conceptwere visually distinct from each other (see examples in Appendix B). The recognizability of all drawings was determined by three independent judges. Only drawings rapidly and correctly identified by all three judges were used for the preparation of the stimulus pairs in the four drawing conditions.

To explain and practice the task requirements in word and drawing conditions, four practice sheets were prepared, one for each identicalness condition (PI or NI) of each stimulus type (words or drawings). To ascertain the unequivocal recognition of the drawings by the participants, the words and drawings used to create the stimulus pairs (as well as those used for task explanation) were copied to flashcards. Prior to experimentation, the participants were asked to match those flashcards representing the same concept.

\section{Procedure}

Participants were tested individually. The experiment was conducted in a quiet room, with the participants sitting in front of a table and the experimenter (a paid graduate student) sitting to their right, slightly to the back to be out of the range of vision during experimentation.

Drawing verification. The experimenter informed the participants that they would first have to sort flashcards, with flashcards representing the same object being put into one pile.

\footnotetext{
${ }^{1}$ Unpointed Hebrew is a mainly consonantal orthography used in school materials above third grade. Prior to this stage, Israeli children read pointed Hebrew where small, physically dissociated diacritical marks (points and dashes) - normally placed below or above a word's consonantal letter string-indicate vowel information. After second grade, however, such vowel diacritics are gradually removed from textbooks and after third grade, reading materials are almost exclusively printed in unpointed Hebrew orthography (for more information on differences regarding pointed and unpointed Hebrew, see Shimron, 1993).
}

The experimenter provided an example using a flashcard set prepared for practice. The participants' proper understanding was then assessed by letting them sort the practice set (mixed anew).

Before asking the participants to sort the flashcards containing the items used for experimentation, the experimenter informed them that this was not a test and that performance time would not be taken. The experimenter also told participants that he would correct them in case they erred. None of the participants demonstrated difficulty in understanding the task requirements. In fact, none made sorting errors that they did not immediately recognize and correct.

Execution of experiment. The participants received test sheets of the four word and four drawing conditions in alternate order, with drawing sheets of opposite syllabic value following word sheets and vice versa (for example, Participant 1 received the monosyllabic PI word condition followed by the bisyllabic PI drawing condition, whereas Participant 2 received the bisyllabic PI drawing condition followed by the monosyllabic PI word condition). To counterbalance practice and fatigue effects, the administration order of the eight test conditions (test sheets) was further rotated in a two-step pace. Performance time (in seconds) and accuracy measures for each experimental sheet were recorded.

Each participant marked the eight experimental sheets in one sequence, according to a specific rotation order. The experimenter first placed a practice sheet with two rows of stimulus pairs corresponding to a specific experimental condition in front of the participants. He then instructed them to mark fields containing the same item twice with a $\checkmark$ and fields containing two different items with an $\mathbf{X}$. The experimenter exemplified the task by correctly marking the stimulus pairs in the first four fields of a practice sheet. He then asked the participants to complete marking the remaining stimulus pairs to ascertain proper understanding of the task. None of the participants manifested problems understanding the task requirements.

Following explanation and practice, the experimenter replaced the practice sheet with one of the test sheets (according to rotation order) covered by an blank sheet. He informed participants that the test sheet contained five rows of fields with stimulus (word/drawing) pairs which they would have to mark as practiced before. The experimenter emphasized that he now would measure time and therefore it is important to work quickly. He instructed participants to start indicating the identicalness of the stimulus pairs from the upper right corner, always proceeding from right to left, ${ }^{2}$ field by field, row by row, until they reach the end. The experimenter further instructed participants not to make corrections in case they err.

When participants indicated their readiness, the experimenter instructed them to position the pencil close to the right-upper corner of the cover sheet and to be ready for marking. He then removed the cover sheet and activated a stopwatch the moment the participants marked the first stimulus pair. Time was stopped when the participants marked the last stimulus pair. This procedure was replicated until the participants completed all eight experimental conditions (test sheets).

\section{Results}

Quantitative (time) and qualitative (error) performances under the different experimental conditions was evaluated by ANOVA, using stimulus type (words, drawings), level of proc- 
essing (PI, NI), and amount of syllabic information (mo- nosyllabic, bisyllabic) as within-subject factors. Because the error rates for all eight experimental conditions were well below one percent, only findings referring to processing time are reported. Table 1 summarizes processing time means and standard deviations for the four word and the four drawing conditions.

The identicalness of drawings was processed notably faster than the identicalness of words, $F[1,27]=19.80, p<.001$. Interestingly, a series of post-hoc analyses using $t$-tests, conducted to further clarify this drawing superiority effect, indicated that drawings were processed faster under both the PI condition (monosyllabic drawing pairs vs. monosyllabic word pairs and bisyllabic drawing pairs vs. bisyllabic word pairs, $t$ [27] $=3.49, p<.01 ; t[27]=4.57, p<.001$, respectively) and the NI condition (monosyllabic drawing pairs vs. monosyllabic word pairs and bisyllabic drawing pairs vs. bisyllabic word pairs, $t$ [27] $=2.20, p<.05 ; t[27]=3.26, p<.01$, respectively).

A significant main effect, $F(1,27)=157.14, p<.001$, was found for level of processing: processing stimulus pairs was significantly faster under the PI condition than the NI condition. As is obvious from Table 1, this PI processing advantage was characteristic for both words and drawings. The ANOVA failed to provide evidence that determining the identicalness of stimulus pairs was notably biased by the syllabic length of the stimulus (monosyllabic vs. bisyllabic).

A significant interaction, $F[1,27]=6.70, p<.05$, between level of processing and stimulus type indicated that the discrepancy in processing speed between PI and NI conditions was more marked for drawing pairs than for word pairs (see Table 1). No other significant interactions between the three main effects were revealed. The fact that the amount of syllabic information did not interact with stimulus type suggests that varying the amount of phonological information had no impact on the processing of either stimulus type.

A series of Pearson product moment correlation analyses were conducted to clarify the relation between the processing of word pairs and the processing of drawing pairs. In all, strong positive correlations in the range of $r=.65, p<.001$, or higher were yielded, indicating that the skills underlying the processing of words were also important for the processing of drawings. Chronbach's Alpha, representing the paradigm reliability, computed with execution times of all eight experimental conditions, was 0.96 .

Table 1.

Processing time means ${ }^{a}$ for monosyllabic and bisyllabic Hebrew words and drawings under PI and NI conditions (standard deviations in parentheses).

\begin{tabular}{llll}
\hline & & \multicolumn{2}{l}{ Type of Identicalness } \\
\hline Stimulus Type & Syllabic Length & PI & NI \\
& Monosyllabic words & $44.65(9.90)$ & $51.14(8.46)$ \\
Hebrew Words & Bisyllabic words & $44.49(9.79)$ & $51.61(9.06)$ \\
& All words & $44.57(9.50)$ & $51.37(8.57)$ \\
& $\begin{array}{l}\text { Monosyllabic } \\
\text { drawings }\end{array}$ & $39.72(8.57)$ & $48.94(7.73)$ \\
Drawings & Bisyllabic drawings & $38.71(8.95)$ & $48.00(8.19)$ \\
& All drawings & $39.22(8.52)$ & $48.47(7.75)$ \\
\hline
\end{tabular}

Note: ${ }^{\mathrm{a}}$ Measurements in seconds.

\section{Discussion}

The impetus behind this study was to further illuminate differences in processing of written words and pictorial stimuli (drawings), with the aim of providing novel insight into existing assumptions. The research hypotheses were primarily based upon the assumption that making a same/different decision under the PI (physically identical) condition, as opposed to the NI (name identical) condition, would reveal differences between words and drawings at two essentially different, yet basic levels of their processing.

Hypothesis 1 predicted that determining the identicalness of two stimuli under the NI condition would take significantly more time than making the very same decision under the PI condition. This is because processing identicalness in the former condition requires a deeper processing of the stimulus. This hypothesis was intended to substantiate the suitability of the experimental paradigm for distinguishing between different levels of processing. A very robust level of processing effects for both words and drawings confirmed the suitability of the experimental paradigm for tracking possible processing differences under conditions altering the depth of processing of these two stimulus types. They also confirmed that the processing of between-stimuli identicalness under the NI condition requires accessing some form of knowledge in LTM (see also Miller, 2005).

Hypothesis 2 predicted that it would take significantly less time to determine the identicalness of two words than of two drawings. This is because verbal processing may be sufficient to recognize the identicalness of two words, rendering the establishment of referential connection to their semantics superfluous (McCann \& Besner, 1987; see also Jackson \& Coltheart, 2001), whereas determining the identicalness of two drawings presumably requires accessing their meaning in a time-consuming process (Job, Rumiati, \& Lotto, 1992; Job \& Tenconi, 2002). This word processing advantage, however, was not assumed to be general, but rather restricted to the NI condition, where recognizing the identicalness of two items requires their processing beyond a perceptual level. Determining identicalness under the PI condition was not expected to reveal processing differences between words and drawings given that, in this condition, processing the perceptual information of the stimuli was sufficient for making a same/different judgment.

Hypothesis 2 was not supported. Table 1 shows that participants consistently processed drawing stimulus pairs significantly faster than the same stimulus pairs presented as written words (Hebrew nouns). This unexpected finding of a drawing processing superiority seems to imply that, to determine their identicalness, the processing of the word pairs proceeded beyond a verbal level; otherwise, performance should have reflected a word processing superiority (see Job \& Tenconi, 2002). The finding of a drawing processing superiority in the PI condition warrants particular attention. It hints at the possibility that, within the information processing system, the processing of verbal and pictorial materials already diverges at a very early processing stage.

Under the NI condition, it should have been possible to determine the identicalness of two words based upon their phonological decoding. In light of the unexpected finding of a drawing processing advantage at both processing levels, examination of the participants' sensitivity to the phonological manipulation (the use of monosyllabic vs. bisyllabic items) is of particular interest. Two specific hypotheses were tested with relevance to the impact of this manipulation. First, it was pre- 
dicted that increasing the number of the syllables composing the word pairs would decrease the speed of processing their identicalness under NI conditions (bisyllabic word pairs being processed significantly slower than monosyllabic word pairs). Second, it was anticipated that a similar syllabic bias would be found also for drawings if accessing their meaning involves the simultaneous retrieval of their linguistic names (Job \& Tenconi, 2002). If, however, the retrieval of their names is not intrinsic to the process underlying the access of their meaning (e.g., Job, Rumiati, \& Lotto, 1992), varying the syllabic length of drawing names was hypothesized to be irrelevant to the processing of their identicalness.

Interestingly, varying the syllabic length of the stimuli was not found to bear on the speed of their processing. This was true whether such stimuli were processed as words or as drawings and whether determining their identicalness demanded reliance on some form of knowledge (NI condition) or not (PI condition). While the absence of a syllabic bias with respect to drawings is in line with the assumption that such stimuli do not trigger the retrieval of their names spontaneously (Job, Rumiati, \& Lotto, 1992), the participants' lack of sensitivity to syllabic length when determining the identicalness of written words challenges the widely held view that readers automatically phonologically decode (name) such stimuli at their encounter (e.g., Paivio, 1986; see also Share, 1995).

A central assumption of the present study was that processing the stimulus pairs at a perceptual level (PI condition) would not distinguish between words and drawings. In other words, it was anticipated that differences in the processing of these two stimulus types would be restricted to instances where determining identicalness requires processing to go beyond the perceptual level (in the NI condition). However, as already stated, drawings were processed faster also under PI conditions. The fact that this processing superiority was replicated in the two syllabic conditions strengthens the validity of this finding. Of interest in this regard is that this processing superiority was notably larger in the PI condition than the NI condition (see Table 1), as reinforced by a statistically significant interaction between level of processing and stimulus type and the absence of a triple interaction of these effects with syllabic length. These findings suggest that the way the human information processing system treats these two stimulus types diverges at the most basic processing levels.

Integrating the current evidence about the processing of pictorial materials and words with previous research (e.g., Job, Rumiati, \& Lotto, 1992; Job \& Tenconi, 2002; Lloyd-Jones \& Humphreys, 1997; McBride \& Dosher, 2002; Paivio, 1986; Paivio \& Csapo, 1973; Weldon \& Roediger, 1987; Weldon \& Coyote, 1996; Wippich, Melzer, \& Mecklenbrauker, 1998), one cannot avoid the conclusion that the processing of information within the human information processing system is optimally attuned to the requirements of a particular task. This conclusion seems particularly sound given that participants in the present study had notably shorter processing times under the PI condition. This implies that they must have determined the identicalness of stimulus pairs at a much earlier processing level under that condition, as compared to the NI condition. This seems to have been the case even though there was nothing to hinder them from processing the PI condition at a deeper level. The fact that such augmented processing did not occur implies that the optimization of processing resources to task requirements is automatic, given, of course, that these task requirements are sufficiently clear. It also suggests that the assumption that drawings automatically evoke their meaning (Paivio, 1986) may not be tenable in its narrow sense.

At first glance, the markedly faster processing of word and drawing pairs under the PI condition fits neatly with the assumption that, in this condition, determining their identicalness was based on a mere analysis of their physical (perceptual) properties. This conclusion, however, ignores two important findings. First, and in contradiction to Hypothesis 2, the participants' performance in the PI condition reflected a notable drawing processing superiority. Second, this superiority was even more marked than it was in the NI condition. One possible explanation for this counterintuitive performance pattern is that written words and drawings vary in their perceptual processibility. Given, however, that participants processed exactly the same words and drawings-although paired differently (see Appendix B) - in the PI and NI conditions, variance in perceptual processibility fails to adequately explain why, of all things, the drawing processing superiority was found to be more enhanced in the PI condition for both monosyllabic and bisyllabic stimulus pairs (see Table 1). In view of such ambiguity, consideration of further explanations for the drawing processing superiority in the PI condition is warranted.

As already argued, the finding of a drawing processing superiority in the PI condition suggests that words and drawings are treated differently from a very early processing stage. Considering this conclusion seriously gives rise to the possibility that the processing advantage found for drawings in the PI condition, as opposed to the NI condition, has different roots. For example, in the PI condition, this processing advantage may indicate that participants processed words beyond a perceptual level when making an identicalness decision, whereas the rapid processing of drawings suggests that the same decision was based, as hypothesized, on a comparison of their physical properties. Given this to be true, the drawing processing superiority found in the PI condition would reflect a propensity of proficient readersprobably due to long-term habituation-to treat written words as linguistic rather than visual stimuli (Jackson \& Coltheart, 2001). This, of course, is not meant to suggest that participants identified the words (retrieved their meaning) when judging their identicalness under the PI condition. Rather, it seems that they made their identicalness decisions only after processing the visual information of the word stimuli to some abstract letter or orthographic knowledge.

As already stated, the rapid processing of drawings under the PI condition suggests that participants focused on their perceptual properties to process identicalness. It thus appears that the semantic coding of pictorial materials is not an automatic reaction to their perception (Paivio, 1986), but is triggered by particular task requirements. Determining the identicalness of drawings in the NI condition-as manifested in notably prolonged processing times — created such a requirement. Interestingly, however, in contradiction to a dual coding hypothesis (Paivio, 1986), there was no evidence that drawings were also encoded verbally. If there had been, processing drawings with bisyllabic names would have taken longer than processing drawings with monosyllabic names. This suggests that both the semantic and verbal coding of drawings may be restricted to instances where it is purposeful for task performance.

To determine identicalness in the NI condition, participants seem to process written words down to a semantic level. Otherwise, the markedly slower processing of word pairs in comparison to drawing pairs makes no sense. Although this time discrepancy is principally in line with findings from other studies (Job, Rumiati, \& Lotto, 1992; Job \& Tenconi, 2002; Lloyd-Jones \& Humphreys, 1997) that have compared the 
processing of words and pictures under conditions (categorization tasks) requiring their semantic processing, the present finding that words were processed slower than drawings remains puzzling. This is because determining their identicalness should have been possible based upon their phonological and/or orthographic representations. Why participants did not use linguistic knowledge to mediate word identicalness (as indicated partly by the absence of a syllabic effect) in the NI condition is not sufficiently clear. However, it should be noted that words were provided in unpointed Hebrew, an orthography in whichdue to substantial vowel omission-the phonological decoding of words out of context becomes highly unreliable (Shimron, 1993). Moreover, some previous research suggests (e.g., Corcoran \& Rouse, 1970) that orthographic knowledge for printed words and handwritten words is represented by different abstractions in LTM. Hence, the possibility that the participants used neither their phonological nor their orthographic knowledge to mediate the visual incongruity between the stimulus words in the NI conditions seems plausible, as would their retreat to a semantic strategy for this purpose.

In summary, findings from the present study and those reported elsewhere (e.g., Job \& Tenconi, 2002; Miller, 2005) suggest that the human information processing system optimizes the processing of information (words, drawing, etc.) according to specific task requirements or task constraints. Stimulus type per se does not seem to determine the depth of its processing, nor does it seem to directly trigger particular modalities of encoding (perceptual, linguistic, semantic, etc.). Rather, what seems to determine these dimensions is the purpose of the processing. Once that purpose is defined, the processing of information seems to proceed to levels that satisfy the task requirements. Findings from the present study suggest, however, that written words may have a unique status in this regard, in that they are treated by proficient readers as linguistic rather than as visual information. As a result, their processing seems to involve their elaboration beyond the perceptual dimension in instances where this is not a prerequisite for adequate task performance, and even at the expense of processing efficiency.

Finally, findings from the present study warrant the conclusion that superiority effects related to the processing of written words and pictorial stimuli reflect artifacts of task requirements rather than inherent characteristics of stimuli. This is probably true whether such effects are observed during the phase of encoding or at the stage of their recall.

\section{Acknowledgements}

I am very grateful to my language editor, Helene Hogri, for her excellent job.

\section{References}

Corcoran, D. W. J., \& Rouse, R. O. (1970). An aspect of perceptual organization involved in reading typed and handwritten words. Quarterly Journal of Experimental Psychology, 22, 526-530. doi:10.1080/14640747008401930

De Zuniga, C. M., Humphreys, G. W., \& Evett, L. J. (1991). Additive and interactive effects of repetition, degradation, and word frequency in the reading of handwriting. In D. Besner, \& G. Humphreys (Eds.), Basic processes in reading: Visual word recognition (pp. 10-33). Hillsdale, NJ: Erlbaum.

Jackson, N. E., \& Coltheart, M. (2001). Routes to reading success and failure: Toward an integrated cognitive psychology of atypical reading. New York: Psychological Press.

Job, R., Rumiati, R., \& Lotto, L. (1992). The picture superiority effect in categorization: Visual or semantic? Journal of Experimental Psychology: Learning, Memory, \& Cognition, 18, 1019-1028. doi:10.1037/0278-7393.18.5.1019

Job, R., \& Tenconi, E. L. (1002). Naming pictures at no cost: Asymmetries in picture and word conditional naming. Psychonomic Bulletin and Review, 9, 790-794. doi:10.3758/BF03196336

Lloyd-Jones, T. J., \& Humphreys, G. W. (1997). Categorizing chairs and naming pears: Category differences in object processing as a function of task and priming. Memory \& Cognition, 25, 606-624. doi:10.3758/BF03211303

McBride, D. M., \& Dosher, B. A. (2002). A comparison of conscious and automatic memory processes for picture and word stimuli: A process dissociation analysis. Consciousness and Cognition, 11, 423-460. doi:10.1016/S1053-8100(02)00007-7

McCann, R. S., \& Besner, D. (1987). Reading pseudohomophones: Implications for models of pronunciation assembly and the locus of word-frequency effects in naming. Journal of Experimental Psychology: Human Perception \& Performance, 13, 14-24. doi:10.1037/0096-1523.13.1.14

Miller, P. (2005). Changes in the processing of letters, written words, and pseudo-homophones: A comparison of fifth graders and university students. Journal of Genetic Psychology, 164, 407-434. doi:10.3200/GNTP.166.4.407-434

Nelson, D. L. (1979). Remembering pictures and words: Appearance, significance, and name. In L. S. Cermak, \& F. I. M. Craik (Eds.), Levels of processing in human memory (pp. 45-75). Hillsdale, NJ: Erlbaum.

Nelson, D. L., Redd, V. S., \& Walling, J. R. (1976). Pictorial superiority effect. Journal of Experimental Psychology: Human Learning and Memory, 2, 523-528. doi:10.1037/0278-7393.2.5.523

Paivio, A. (1975). Coding distinctions and repetition effects in memory. In G. H. Bower (Ed.), The psychology of learning and motivation (pp. 179-214). New York: Academic Press.

Paivio, A. (1986). Mental representations: A dual-coding approach. New York: Oxford University Press.

Paivio, A. (1991). Dual coding theory: Retrospect and current status. Canadian Journal of Psychology, 45, 255-287. doi:10.1037/h0084295

Paivio, A. (1995). Imagery and memory. In M. S. Gazzaniga (Ed.), The cognitive neurosciences (pp. 977-986). Cambridge, MA: MIT Press.

Paivio, A., \& Csapo, K. (1973). Picture superiority in free recall: Imagery or dual coding? Cognitive Psychology, 5, 176-206. doi:10.1016/0010-0285(73)90032-7

Posner, M. I., \& Mitchell, R. R. (1967). Chronometric analysis of classification. Psychological Review, 74, 392-409. doi: $10.1037 / \mathrm{h} 0024913$

Potter, M., Kroll, J., Yachzel, B., Carpenter, E., \& Sherman, J. (1986). Picture in sentences: Understanding without words. Journal of Experimental Psychology: General, 115, 281-294. doi:10.1037/0096-3445.115.3.281

Share, D. L. (1995). Phonological recoding and self-teaching: Sine qua non of reading acquisition. Cognition, 55, 151-218. doi:10.1016/0010-0277(94)00645-2

Shimron, J. (1993). The role of vowels in reading: A review of studies of English and Hebrew. Psychological Bulletin, 114, 52-67. doi:10.1037/0033-2909.114.1.52

Weldon, M. S., \& Coyote, K. C. (1996). Failure to find the picture superiority effect in implicit conceptual memory tests. Journal of Experimental Psychology: Learning, Memory, and Cognition, 22, 670-686. doi:10.1037/0278-7393.22.3.670

Weldon, M. S., \& Roediger, H. L. (1987). Altering retrieval demands reverses the picture superiority effect. Memory \& Cognition, 21, 519-528. doi:10.3758/BF03197183

Wippich, W., Melzer, A., \& Mecklenbrauker, S. (1998). Picture or word superiority effects in implicit memory: Levels of processing, attention, and retrieval constraints. Swiss Journal of Psychology, 57, 33-46. 


\section{Appendix A: Test Sheet of PI Condition for Monosyllabic Words}

\begin{tabular}{|c|c|c|c|c|c|c|c|}
\hline טיל טיל & דלי דלי & תיק תות & $\begin{array}{c}010 \text { oln } \\
\times\end{array}$ & $f_{3}$ I $_{3}$ & דלי פוס & מיק ח'ק & כוס כוס \\
\hline
\end{tabular}

\begin{tabular}{|c|c|c|c|c|c|c|c|}
\hline אוס & O10 & o & חוט כיס & טיל תות & סיר סיר & תומ מומ & פיל דלי \\
\hline חוט חוט & ifo & טיל פוס & סות ס/ת & כים תוף & כיס כיס & תוק מות & כוס \\
\hline כיס כים & fio fio & 012 ifo & תות תות & תוף תוף & 01080 & סיכ מו & תיק תיק \\
\hline פיל פיל & תוף פיל & סיר חוט & ริ/ก รి/ก & 810810 & סיר חיק & oln oln & סוף מ'ק \\
\hline
\end{tabular}

a The format of the experimental sheet is reduced in size (A4 instead of A3 format). ${ }^{\text {b}}$ The $\checkmark$ 's and $\mathbf{X}$ 's were not indicated on the original experimental sheet, but serve merely as an illustration of task requirements.

\section{Appendix B: Transcription of Monosyllabic and Bisyllabic Hebrew Words Used and} Their Arrangement into Word Pairs ${ }^{\mathrm{a}}$

\begin{tabular}{|c|c|c|c|c|c|c|c|}
\hline \multicolumn{8}{|c|}{ Monosyllabic Stimulus Pairs } \\
\hline \multirow[b]{2}{*}{ Pair } & \multicolumn{2}{|c|}{ Physically Identical (PI) } & \multicolumn{2}{|c|}{ Name Identical (NI) ${ }^{\circ}$} & \multicolumn{3}{|c|}{ Stimuli Transcription } \\
\hline & $\checkmark$ Response & X Response & $\checkmark$ Response & X Response & \multirow{2}{*}{$\begin{array}{l}\text { תeb. } \\
\text { תוף }\end{array}$} & \multirow{2}{*}{$\begin{array}{l}\text { Phon. } \\
\text { tof }\end{array}$} & \multirow{2}{*}{$\begin{array}{l}\text { English } \\
\text { drum }\end{array}$} \\
\hline 1 & תוף תוף & תוף יל & תוף תוף & מתו פיל & & & \\
\hline 2 & פיל פיל & פיל דלי & סי & 20 & 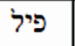 & pil & elephant \\
\hline 3 & 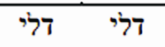 & דלי כוס & אילי & כוס & 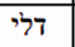 & dli & bucket \\
\hline 4 & 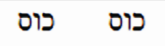 & 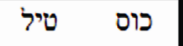 & כוס כוס & כוס טיל & 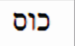 & kos & glass \\
\hline 5 & טיל & טיל תות & סיל & תות & 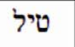 & til & missile \\
\hline 6 & $\mathrm{~s} / \mathrm{s} \mathrm{s} / \mathrm{s}$ & תומ מת & תומת תות & מתומ תיק & 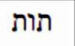 & tut & strawberry \\
\hline 7 & ת'ק ת'ק & מיק סות & מיק תיק & מ'ק סיר & 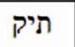 & tik & bag \\
\hline 8 & סית סית & ס' & סית & ס'ת דוט & סיר - - - - & $\operatorname{sir}$ & pan \\
\hline 9 & Gln Gln & Dוo & הום & (n & זוט & hut & thread \\
\hline 10 & כ'ס כים & ร゚/n ס & כים כיס & כ'ס & כיס & kis & pocket \\
\hline \multicolumn{8}{|c|}{ Bisyllabic Stimulis Pairs } \\
\hline 1 & טוס & טוס ספל & סוס & & טוס - - - - & tavas & peacock \\
\hline 2 & ספל & ספל סרט & לס & סרט & ספל & sefel & cup \\
\hline 3 & סרט סרט & סרט גרב & $6>0$ & 6 600 & 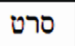 & seret & movie \\
\hline 4 & גרב & גרב להם & גרב & לחם & גרב & gerev & sock \\
\hline 5 & להם להם & להם & להם & ברז & 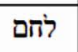 & lehem & bread \\
\hline 6 & 3OD SOD & San 300 & סכל ברו & סכל הבל & ברז & berez & faucet \\
\hline 7 & fan fan & fes fan & אברל & א דגל & הבל - 1 & hevel & rope \\
\hline 8 & $\delta_{C 3} \delta_{C 3}$ & ene $\delta_{C B}$ & דג & אמש שd? & 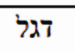 & degel & flag \\
\hline 9 & ene ene & DOO eNe & שמש eNe & ספר ene & שמש & shemesh & sun \\
\hline 10 & $200 \quad 200$ & 016200 & 200 ספר & 200 טוס & ספר & sefer & book \\
\hline
\end{tabular}

${ }^{a}$ The word pairs prepared for each condition appeared twice, randomly distributed, within the 40 fields comprising a test sheet. ${ }^{\text {b }}$ Both word stimuli of the pair appear either in print or in cursive script. 'One word stimuli of the pair is in print and the other in cursive script. 